\title{
AESTHETIC ASPECT OF EMOTIVENESS OF POETIC TEXT
}

\author{
Inna Redka \\ Ph.D., Assistant Professor, Borys Grinchenko Kyiv University, Ukraine \\ e-mail: i.redka@kubg.edu.ua, orcid.org/0000-0002-3088-9651
}

\section{Summary}

The study looks for ways of analyzing the aesthetic aspect of emotiveness in a poem. To accomplish the aim, the author undertakes an attempt to study the essence of the image of aesthetic feeling. Since a poetic text appears to be a complex unity of notional, emotive, and aesthetic codes, the methods of cognitive analysis are employed to formalize deep cognitive and emotive constructs that give rise to aesthetic senses within a poetic text. The study relies on the statement that an image of aesthetic feeling has an emergent nature which means that it appears in the process of poetic text writing as a result of a creative impulse of the author (O. Mandelstam). In the study, the image of aesthetic feeling is regarded as an emotive image of the highest level. On the one hand, it is directed at some well-established aesthetic categories, and on the other, it reveals the author's attitude to them which is manifested through a sophisticated network of images. A step-by-step analysis of Shel Silverstine's poem "A Light in the Attic" has been suggested to illustrate a possible way of uncovering image(s) of aesthetic feelings inscribed in the text.

Keywords: emotiology, cognitive linguistics, emotive unit, image of aesthetic feeling.

\section{DOI: https://doi.org/10.23856/4612}

\section{Introduction}

Despite numerous researches dedicated to different categories of poetic texts, many aspects of poems still remain uncommented and unexplained. Among the issues that require further clarification is the aesthetic side of emotiveness of a poetic text. Since a poem appears to be a "semiotic vehicle" of deep aesthetic senses on the one hand, and a container of emotional images of its addresser, on the other, it is necessary to find out how these layers of information interact to produce emotiveness of a higher level which leaves far beyond the basic emotional images of the author.

Poetic texts incorporate three main codes closely connected with each other: the notional, emotive, and aesthetic. Each of these codes taken separately is extensively highlighted in research works within different branches of poetics. Thus, the notional code is being investigated within the cognitive paradigm of linguistics, which aims at explaining how the knowledge that a person acquires from the natural environment transforms into networks of images that underlie the verbal design of a poetic text. In this field, researches are mainly focused on concepts modelling and ways of their organizing in poetic texts to produce intricate senses (Tsur R., Byelyekhova L., Marina O., Gorchak T., Malashchuk-Vyshnevska N.). The emotive code of poetic texts is studied in the realm of emotiology which is also known as linguistics of emotions (Shakhovsky V., Bolotnova N., Freeman M., Vorobyova O.). The researches in this field aim at uncovering the ways how emotional images of the addresser are implemented in poetic texts. Since human cognition is inseparably connected with emotions, this approach also relies on cognitive linguistics methods and data to model the dynamic configurations of 
emotional images in poetic texts (Tsur R., Freeman M., Redka I.). Finally, poetic texts would never have been poetic if it had not been for their aesthetic code. Research work in this direction is centered upon clarifying the issues of aesthetic functions of fictional texts and poems in particular (Gliebkin V., Bolotnova N.); correlation of emotional images and aesthetic categories (Knaller S., Nieborsina N.).

The current research aims at revealing the essence of an image of aesthetic feeling of the addresser construed in a poetic text. In other words, the aim of the paper is to comment on aesthetic aspects of emotiveness in a poetic text which basically presupposes setting the links between the codes mentioned above. The aim can be achieved through the following steps: 1) identifying notional and emotive codes in poetic texts; 2) setting the correlation between them in the text under analysis; 3) considering the peculiarities of aesthetic features of poetic texts in general; and finally, 4) setting the correlation between the notional, emotive, and aesthetic codes in the text taken for analysis. The case will be illustrated on the basis of the poem "A Light in the Attic" by Shel Silverstein.

\section{Notional and emotive codes in poetic texts}

In any work of art, a code is regarded as a system of images specific for every creative method. A poetic image is verbal in its nature. However, its structure is by far larger than its verbal design. In cognitive poetics, a verbal poetic image is regarded as a three-dimensional structure incorporating verbal, conceptual, and preconceptual levels (Byelyekhova, 2002). Verbally, the image can be represented by such figures of speech as metaphor, metonymy, or oxymoron. So, basically a verbal image is any linguistic means that is based on the tenor-vehicle-ground model in the classical terminology or the one that is based on some kind of conceptual mapping in terms of cognitive linguistics.

On the conceptual level, the poetic image is based on mapping which is regarded as a conceptual mechanism of projecting a bundle of features from one concept onto the other on the basis of analogy (metaphor), stand-for relations (metonymy), and contrast (oxymoron) (Lakoff and Johnson, 1980; Byelyekhova, 2002). The preconceptual level of such mappings is represented by subconscious forms such as cultural and psychological archetypes (Byelyekhova, 2002; Tsepkalo, 2021).

Poetic images are never used in isolation within a poetic text. They are rather organized into specific networks to create more complex unities like extended metaphors or other hybrid formations. The notional code of the poem gets enacted by the force dynamics of the emotional schemata (Freeman, 2013) of the images. Emotional images that poetic images trigger appear to be the uniting force in poetic texts. In other words, the networks of verbal poetic images are stipulated and then accompanied by the emotional images. The latter appear not in the chaotic form, but in specific configurations. Before we get down commenting on their nuances, let us first clarify some points in the terminology of emotiveness.

Emotionality of the author gets reflected in emotiveness of the poetic text that he / she creates (Shakhovsky, 2016). Emotiveness is explained as a category which comprises the form, content, and functions of linguistic means that render the nuances of the author's emotional experience in texts including the poetic ones. In this case, the form is constituted by the figurative means that possess emotiongenic power (or emotion-triggering potential). The content appears to be an emotional image or their scope of the addresser. The figurative means are often intended to render the emotions of the author. So, such they fulfill the emotive function in poems. Thus, we approach the definition of the emotive code of the text which is regarded as 
verbally marked, conceptually, and pragmatically predetermined system of emotive units that encode various emotions of the addresser and reflects the author's intention and the general pathos of the text (Bolotnova, 2013: 259).

Emotiveness of poetic texts is represented by emotive units. "Emotive unit" is a term that denotes an emotional image / feeling encoded in the text with linguistic means (Shakhovsky, 2016). To illustrate the case, we will take the lines from the poem by E. Dickinson: "'Hope' is the thing with feathers - / That perches in the soul". In this fragment, the feeling of hope is presented through the periphrastic image that uncovers its tremulous and at the same time life-affirming features.

Emotive units fall into different groups depending on the criteria that underlies their grouping. With regard to the ways of encoding the emotional information, emotive units fall into nominative, descriptive, and expressive (Shakhovsky, 2016: 45). Nominative emotive units name emotional images directly in the text, for example, sadness, joy, fear, etc. They are rarely used in poetry due to their scarce capacity to render the unique individual feelings. Expressive and descriptive emotive units are more frequent in this respect. Expressive emotive units are the cases of the figurative language use. The author's emotions give an impetus for their appearance and they get fixed in such units. The term "descriptive emotive unit" speaks for itself: the cases of description give an insight into situations in which the person may experience some sort of feelings.

The above given classification correlates with the other one: emotive units can be explicit (nominative) and implicit (expressive and descriptive). Implicit emotive units can be traced in a literary text only if its context is taken into consideration.

On the basis of contextual criterion, emotive units can be classified into micro, meso, and mega units (Redka, 2020). They appear within the emotional situations created in the text. Micro emotive units converge to create meso units in the text which are usually marked by contrastive features. Their interaction creates the mega emotive unit which represents a complex emotional image of a higher than basic level. It can be either an image of cultural, social, or aesthetic emotion of the addresser.

The reverse process of reconstructing the emotional experience of the addresser by the recipient of a text is enabled by the methods of conceptual modelling of the emotional images. The ultimate goal of it is the model of emotiveness that renders the information about the intensity and valency of the emotional image (or images).

Summing everything up, we will mention once again that notional and emotive codes go always together. They may coincide in the form which embraces both notional and emotive content.

\section{Aesthetic code in poetic texts}

Every poetic text unfolds its own aesthetic programme. In other words, the linguistic means are directed at its implementation. It presupposes setting the correlation between the content of the text and aesthetic categories such as the beautiful, sublime, tragic, comic, ugly, plain, etc. (Briedikhin and Davydova, 2016: 212). It becomes possible only through the analysis of emotional imagery in poems.

It is believed that there are strong correlations between emotions of a person and the aesthetic categories (Boriev, 1988: 37-101). For example, calmness, joy, and emotional balance are associated with such aesthetic concept as harmony; embarrassment with chaos; laughter with the comic; courage with the heroic, etc. In a poetic text, the emotive model which forms 
itself on the basis of the author's conceptual map correlates with the aesthetic categories that are shaped by the social and cultural context he/she lives in.

Since basic concepts converge to produce more sophisticated networks of senses (macroimages and metaimages) in a poetic text, the emotional images also undergo the process of development: they interact creating meso and mega emotive units. Megaemotive unit appears to be a complex construal which represents social or cultural emotions that are marked by aesthetic values. In other words, they are called "aesthetic emotions".

There are several approaches to defining the notion of an "aesthetic emotion". It is defined as: 1) an emotion of a higher level that is generated by the addresser in the process of poetic text writing (Mandelstam, 1967; Knaller, 2017; Nieborsina, 2016); it usually comes as a result of creative impulse of the poet; 2) pathos of a literary text (Malm, 2012); 3 ) a reaction of the recipient to the literary work (Nünning, 2017). The third definition does not go in line with the current research; therefore, we will pay more attention to the first and the second ones.

Aesthetic emotions do not have special forms of expression in poetic texts and manifest themselves in specific ways (Knaller, 2017: 21). Methodologically they are the most difficult object for analysis. They provide insights into one's personality through the reaction and assessment of particular situations (Knaller, 2017: 21). Aesthetic emotions never appear as simple reflections on life situations. Specific features of aesthetic emotion lie in juxtaposing the approved and disapproved attitudes towards a particular object (Knaller, 2017: 22) which results in such processes as purification, sensibilization, insights formations, etc. that are experienced by the author.

Aesthetic emotion correlates with the term "pathos" (from Gr. $\pi \dot{\alpha} \theta o \varsigma$ meaning feeling, emotion) which is defined as the author's style or manner of rendering his emotional elation and inspiration (Malm, 2012: 267). The meaning of the word pathos points at some kind of embarrassment and lack control as to emotions and passions (Malm, 2012: 267). Thus, the aesthetic emotion manifests itself in the so-called "form of pathos" (the term had been suggested by S. Eisenstein).

Aesthetic code of a text forms itself on the basis of the image-bearing code which also has an emergent nature, especially if we take into account the statement that poetic images are generic ones: they give rise to other poetic images in poems (Mandelstam, 1967). All these poetic processes go in line with aesthetics of spontaneity, the principles of which have been formulated by O. Babelyuk (Babeyuk, 2015).

Thus, let us conclude that the aesthetic emotion emerges in the process of creative writing, gets fixed in the fictional text in the "form of pathos", through which it is communicated to the recipient.

\section{Aesthetic feeling as a construct: a study of "A Light in the Attic"}

Let us now consider how the codes mentioned above interact to produce imagery of aesthetic feelings of the author in the poem "A Light in the Attic" written by the American poet Shel Silverstein (1930-1999) (Silverstein, 2010).

\section{A Light in the Attic}

There's a light on in the attic.

Thought the house is dark and shuttered,

I can see a flickerin' flutter,

And I know what it's about. 
There's a light on in the attic.

I can see it from the outside.

And I know you're on the inside... lookin' out.

The analyzed poetic text is intended for children. On the one hand, it contains simplistic linguistic means including two cases of colloquialisms (flickerin', lookin'). On the other hand, its imagery is organized so that it produces a riddle which can be easily solved.

The poem is based on the networks of contrastive images, with the attic and light forming the focus of the author's attention. Thus, we can single out two image-bearing spaces: 1) that of the house with the attic and light on in it and 2) that of the observer (the persona), marked by the pronoun $I$.

The image-bearing space of the house is marked by the adjectives dark, shuttered. The contrastive part of the dark house is the light in the attic which manifests itself through the image of flickering flutter. As the poem unfolds, the image of the dark house loses its dark features and instead it is getting lighter until it finally transforms into a human being, whose presence is acknowledged with the pronoun you. Despite short form of the poetic text, the author plays on the central image enriching it with unexpected details. Thus, the cumulative image is construed in the text: the shuttered house becomes lit, and in this light the features of a human being become visible whose consciousness presumably throws light from within. We deal with the allegoric image which gets restated in the second half of the poem. So, the text is based on the network of conceptual metaphors which progressively generate one another: the stranger is a shuttered house $\rightarrow$ the attic is head $\rightarrow$ eyes are the source of light $\rightarrow$ eye contact is light shedding. Finally, the emergent image makes itself visible through $I-$ you interaction in the text: socializing is light exchanging which entangles the massage of the text.

The author's artistic play on dark and light images is mediated by the emotional attitude towards the situation he reflects on. Such creative steps result in appearance of the emotional situation which can be called "Human Acquaintance": the bundle of emotional images creates specific emotiveness in the text. The emotive units in this poem are implicit. They can be reconstructed on the basis of 1) the theory of colour symbolism Max Lüscher (Lüscher, 2004) that enables decoding of emotional images on the basis of colour preferences of a person and 2) the context of the poem.

The image of dark colour (pertaining to the house) is associated with lack of knowledge of the observer; it signals about the intrigue and interest. Light colours, on the contrary, possess the opposite axiological meaning. They stand for hope, optimism, anticipation of positive events. In the context of the poem, together with the light colour comes the insight that communication brings some things to light.

As image-bearing space in the poem unfolds, dark image gets superseded by light which acquires more intensity. On the verbal level of the text, the dark image appears only once and it is specified with the attribute shattered. Contrary to this, the light image is foregrounded and intensified by the repetition: There's a light on in the attic.

The image of light is not shade specific. It more deals with some sort of illumination the dynamic image of emotional power that comes from within a person and correlates with emotions of hope and excitement. Thus, the emotive units are organized into a so-called "peak" with the most positive image appearing on the top as the source of light that clears up darkness. So, the conceptual nodes are organized to create a gradation, and this gradation is accompanied by the emotive climax. Thus, we come across the emotive unit of positive valency and rising intensity - the image of exciting comfort of friendliness and communication. 
The emotive trajectory of the poem which represents the curve that tracks the flow of a person's emotions including such emotive nodes as intrigue-interest-excitement.

So, it becomes clear that the imagery of aesthetic feelings is not a superfluous formation. It forms itself gradually together with the notional and emotive codes in the text. In the context of the poem, the image of aesthetic feeling is all about the value of human contact which is as precious as light.

\section{Conclusions}

All three codes in poetic texts are interconnected. The notional code of a poem is stipulated by the emotions of the poet and gets accompanied by the emotive code. Both notional and emotive codes appear in the cultural context which determines the aesthetic values of the poetic text. All three codes have the emergent features: they are being formed in the process of poetic text writing and appear as a result of the creative impulse of the author.

\section{References}

Babelyuk O.A. (2015). Poetyka spontannosti postmodernistskogo naratyvu. Zapysky z romano-germanskoyi filologiyi. Vyp. 1. http://nbuv.gov.ua/UJRN/zrgf_2015_1_6.

Bolotnova N.S. (2013). O sviazi emotivnogo i esteticheskogo kodov poeticheskogo teksta. Chelovek v kommunikatsii: ot kategorizatsii emotsii k emotivnoi lingvistike. Sbornik nauchnikh trudov, posviashchennyi 75-lietiyu professora V.I. Shakhovskogo. Volgograd. [in Russian] Boriev Yu.B. (1988). Estetika. Moskva: Politizdat. [in Russian]

Briedikhin S.N., Davydova L.P. (2016). Poeticheskiy tekst kak kommunikativno-esteticheskaya kategoriya. Gumanitarnyie i yuridicheskiye issledovaniya. № 2. URL: https://cyberleninka.ru/ article/n/poeticheskiy-tekst-kak-kommunikativno-esteticheskaya-kategoriya. [in Russian]

Byelyekhova L.I. (2002). Slovesnyi poetychnyi obraz v istoryko-typologichniy perspectyvi: lingvokognityvnyi aspect (na materiali amerykanskoyi poeziyi). Kherson: Aylant. [in Ukrainian] Freeman, M.H. (2013). The Influence of Anxiety: Poetry as a Theory of Mind. Kognitsiya, kommunicatsiya, discurs. C 6. URL: https://drive.google.com/file/d/1XETRyGpzDXy2mN2rJwLTqY-XBNJBp3T0/view.

Knaller, S. (2017). Emotions and the Process of Writing. Writing Emotions: Theoretical Concepts and Selected Case Studies in Literature. Bielefeld. URL: www.jstor.org/stable/j.ctv1wxt3t.4.

Lakoff, G., Johnson M. (1980). Metaphors We Live By. Chicago: The University of Chicago Press.

Lüscher M. (2004). Otsenka lichnosti posredstvom vybora tsveta. Tsvetovoi lichnostnyi test. Minsk: Harvest. [in Russian]

Malm M. (2012). The Role of Emotions in the Development of Artistic Theory and in the System of Literary Genres. The Making of the Humanities. Amsterdam University Press.

Mandelstam O. (1967). Razgovor o Dante. URL: https://rvb.ru/20vek/mandelstam/slovo_i_kultura/01text/01 text/13.htm. [in Russian]

Nieborsina N.P. (2016). Poeticheskiy discurs: esteticheskiy aspect tekstualnosti. Problemy semantyky, pragmatyky nf kognityvnoyi lingvistyky. № 29. Kyiv. [in Russian]

Nünning V. (2017). The Affective Value of Fiction. Presenting and Evoking Emotions. Transcript Verlag. 
Redka I.A. (2020). Merezhi emotyvnykh kodiv poetychnogo tekstu (na materiali virshiv V. Stivensa "The Planet on the Table”). Zakarpatsky filologichni studiyi. Uzhgorod: Helvetyka. [in Ukrainian]

Shakhovsky V.I. (2016). Dissonans ecologichnosti v kommunikativnom kruge: cheloviek, yazyk, emotsii [Dissonance of ecology in communicative circle: man, language and emotions]. Volgograd. [in Russian]

Silverstine Sh. (2010). A Light in the Attic. URL: https://www.poemhunter.com/poem/a-lightin-the-attic/.

Tsepkalo, T. (2021). THE MYTHOLOGEM OF THE MOON IN THE POETRY OF THE UKRAINIAN LITERARY PERFORMANCE GROUP BU-BA-BU. Scientific Journal of Polonia University, 40(3), 98-102. https://doi.org/10.23856/4012. 